\title{
The effect of titanium dioxide nanoparticles injection in neonatal period on ovaries in
} mature rats

\author{
Noori Ali $1{ }^{*}$, Baghbadorani Azita Amiri ${ }^{2}$ and Golozar Melika ${ }^{1}$ \\ ${ }^{1}$ Department of Biology, Falavarjan Branch, Islamic Azad University, Isfahan, Iran. \\ 2 Department of Biology, University of Payame Noor, Isfahan, Iran.
}

Publication history: Received on 15 December 2018; revised on 10 January 2019; accepted on 14 January 2019

Article DOI: https://doi.org/10.30574/gscbps.2019.6.1.0160

\begin{abstract}
Titanium dioxide nanoparticles are one of the most widely used materials in various industrial and biological fields. In this study, due to the importance of reproduction in organisms, the toxicity of titanium oxide nanoparticles was investigated on ovaries. In this experimental study, concentrations of 50, 100 and $150 \mathrm{mg} / \mathrm{kg}$ titanium dioxide nanoparticles $\left(\mathrm{TiO}_{2} \mathrm{NPs}\right.$ ) with10-20 nm diameter were injected (IP) into immature female (age 35-40 days) for 5 consecutive days. Blood collection was performed three months after the last injection (at puberty) and the levels of hormones (LH, FSH, estrogen and progestron) in the serum were measured by ELISA. After anesthesia and dissection of animals, tissue sections of ovary were prepared and stained with hematoxylin-eosin. Then, the morphological status of ovarian tissue was investigated by optical microscopy. Data were analyzed using ANOVA. Results showed that weight of body and levels of LH and FSH in treated groups did not change significantly. Whereas, the amounts of estrogen and progesterone hormones increased significantly in the concentration of $150 \mathrm{mg} / \mathrm{kg}$ of TiO2 NPs. The TiO2 NPs caused histopathologic changes in the ovary including loss of Graafian follicles, destruction of follicles wall, reducing the thickness of Granulosa and Thec layers. Also, there was a significant decrease in the number of Corpus luteum, growing and Graafian follicles at concentrations of 100 and $150 \mathrm{mg} / \mathrm{kg}$. It appears that injection of concentrations higher than $50 \mathrm{mg} / \mathrm{kg}$ of $\mathrm{TiO}_{2} \mathrm{NPs}$ in the pre-pubertal period leads to impaired ovarian activity and structure after puberty, however further studies are needed to solidify fertility reduction in these treatments.
\end{abstract}

Keywords: Ovarian tissue; $\mathrm{TiO}_{2}$ nanoparticles; Sex hormones

\section{Introduction}

Nanotechnology has been very influential in various fields of science and research and has led to significant advances in all sciences related to nanomaterials $[1,2]$. Nanoparticles have more specific properties than larger sized materials, which make them effective in biological fields [3-5]. Due to their very small dimensions and highly reactive levels, they can easily pass through biological bariers and accumulate in the body organisms [6, 7]. Therefore, toxicity and side effects of nanoparticles are very likely on the environment and organisms $[8,9]$. Research showed material at the nano size are more toxic than the large sizes materials, because they are highly reactive and cause oxidative stress in animals and human [10]. The toxicological effects of nanoparticles is still under investigation and their effects on biological systems incomplete $[11,5]$.

Titanium dioxide $\left(\mathrm{TiO}_{2}\right)$ is the world's first industrial product of nanomaterials in the world and have been widely used due to their strong catalytic activity and is used in pharmaceutical, cosmetics and paint industries. $\mathrm{TiO}_{2} \mathrm{NPs}_{\mathrm{s}}$ can be

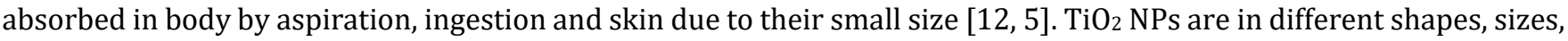
chemical compositions and have four crystalline polymorphic forms that anatase and rutile are the most common forms

\footnotetext{
${ }^{*}$ Corresponding author

E-mail address: ali.noori55@gmail.com
} 
[13]. Its photocatalytic properties have been utilized to remove contaminants from water and air [14]. Various studies have been examined the effects of $\mathrm{TiO}_{2}$ nanoparticles on different organisms $[15,16]$. But since the most sensitive organs, especially in the neonatal period, are gonads and previous studies have often been reported on adults [17]. The purpose of this study was to investigate the toxicity of titanium dioxide nanoparticles in pre-puberty period on the pituitary gonad axis and oogenesis.

\section{Material and methods}

\subsection{Preparation of TiO2 nanoparticles}

TiO2 NPs with diameter of 10-20 nm and purity of 99.9\% were prepared from Neutrino Company in Tehran of Province, Iran. The characteristics of nanoparticles used are based on previous research [16]. The 50, 100 and $150 \mathrm{mg} / \mathrm{kg}$ concentrations of the nanoparticles were prepared in normal saline, then, a relatively uniform suspension was prepared using ultrasonic waves (for 20 minutes, a temperature of $4^{\circ} \mathrm{C}$ and a range of $40 \%$ ).

\subsection{Animals}

The immature female Wistar rats (40-50 g) were obtained from from Isfahan University of Medical Sciences. Animals were kept in laboratory conditions $\left(20-23{ }^{\circ} \mathrm{C}\right.$ and natural light) for a week to adaptation. Different concentrations of TiO2 nanoparticles $(50,100,150 \mathrm{mg} / \mathrm{kg})$ were injected IP into three groups of treatment and normal saline into the control group ( 5 consecutive days) [18]. The animals were anesthetized and the blood samples were collected 3 months after the last injection of TiO2 NPs (adult rats). The hormones levels such as LH, FSH, estrogen and progesterone were assayed using autoanalyzer (Hitachi Automatic Analyzer, 17, Japan). Then, to observe the morphological changes of the ovarian tissue and the number of different follicles (Corpus luteum, growing and Graafian follicle) from each group, three rats were dissected after anesthesia and histological sections were prepared by staining hematoxylin-eosin (a total of 36 tissue lams) from their ovary. Histopathologic studies were performed by a microscope (Olympus CX22LED) equipped with a camera (Canon Eos 760D 18, Japan). Moreover, animals were weighed before and after treatment. This research was approved in advance by the department of biology, Falavarjan branch, Islamic Azad University Ethics Committee.

\subsection{Statistical analysis}

The mean of different factors were compared between treatment and control groups by one-way ANOVA and Duncan's tests (22 software).

\section{Results}

\subsection{Hormonal changes}

The comparison of weight changes in different groups showed that injection of $\mathrm{TiO}_{2}$ nanoparticles did not affect animal weight gain (Table 1). Also, there was no significant change in the level of $\mathrm{LH}$ and $\mathrm{FSH}_{\text {in }}$ the exposed groups of $\mathrm{TiO}_{2}$ nanoparticles compared to control. Whereas, the amounts of estrogen and progesterone increased significantly in concentration of $150 \mathrm{mg} / \mathrm{kg}$ TiO2 NPs compared with other groups $(\mathrm{P}<0.05)$ (Table 2). On the other hand, the numbers of Growing follicles decreased significantly in groups exposed to TiO2 NPs $150 \mathrm{mg} / \mathrm{kg}$ concentration. Also, Graafian follicles decreased significantly in recipient groups of $100,150 \mathrm{mg} / \mathrm{kg} \mathrm{TiO}_{2} \mathrm{NPs}_{\text {in }}$ a dose-dependent manner $(\mathrm{P}<0.001)$. Moreover, the numbers of Corpus Luteum decreased significantly in the treatment group of $100 \mathrm{mg} / \mathrm{kg} \mathrm{TiO} 2 \mathrm{NPs}$ ) $(\mathrm{P}<0.01)$. In fact the numbers of Growing and Graafian follicles were correlated with $\mathrm{TiO}_{2}$ NPs concentration $($ Table 3$)$.

Table 1 Weight changes in rat after injection of TiO2 NPs

\begin{tabular}{lll}
\hline Group & Weight-1 (g) & Weight-2 (g) \\
\hline Control & $42.31 \pm 3.12$ & $162.23 \pm 7.89$ \\
$50 \mathrm{mg} / \mathrm{kg} \mathrm{TiO}_{2} \mathrm{NPs}$ & $45.40 \pm 2.46$ & $173.25 \pm 6.13$ \\
$100 \mathrm{mg} / \mathrm{kg} \mathrm{TiO}_{2} \mathrm{NPs}$ & $47.10 \pm 1.36$ & $172.65 \pm 4.56$ \\
$150 \mathrm{mg} / \mathrm{kg} \mathrm{TiO}_{2} \mathrm{NPs}$ & $43.15 \pm 2.15$ & $169.37 \pm 4.35$ \\
P-value & $\mathrm{P}>0.05$ & $\mathrm{P}>0.05$ \\
\hline
\end{tabular}


Table 2 The effects of $\mathrm{TiO}_{2}$ NPs injection on hormone levels

\begin{tabular}{|c|c|c|c|c|}
\hline Hormone & Control & $\begin{array}{l}50 \mathrm{mg} / \mathrm{kg} \\
\mathrm{TiO}_{2} \mathrm{NPs}\end{array}$ & $\begin{array}{l}100 \mathrm{mg} / \mathrm{kg} \\
\mathrm{TiO}_{2} \mathrm{NPs}\end{array}$ & $\begin{array}{l}150 \mathrm{mg} / \mathrm{kg} \\
\mathrm{TiO}_{2} \mathrm{NPs}\end{array}$ \\
\hline $\mathrm{LH}(\mathrm{miu} / \mathrm{ml})$ & $0.82 \pm 0.67$ & $0.54 \pm 0.27$ & $0.56 \pm 0.36$ & $0.78 \pm 0.33$ \\
\hline FSH (miu/ml) & $0.18 \pm 0.04$ & $0.16 \pm 0.06$ & $0.19 \pm 0.04$ & $0.15 \pm 0.05$ \\
\hline Estrogen (pg/ml) & $63.79 \pm 13.78$ & $66.31 \pm 26.27$ & $93.70 \pm 41.50$ & $114.83 \pm 52.27^{*}$ \\
\hline Progesterone (ng/ml) & $4.64 \pm 2.08$ & $3.82 \pm 1.05$ & $2.81 \pm 1.05$ & $6.82 \pm 2.15^{\odot}$ \\
\hline
\end{tabular}

Table 3 The effects of $\mathrm{TiO}_{2}$ NPs injection on follicles number of ovary

\begin{tabular}{llllll}
\hline & Control & $\begin{array}{l}\mathbf{5 0} \mathbf{~ m g} / \mathbf{k g} \\
\text { TiO2 NPs }\end{array}$ & $\begin{array}{l}\mathbf{1 0 0} \mathbf{~ m g} / \mathbf{k g} \\
\text { TiO2 NPs }\end{array}$ & $\begin{array}{l}\text { 150 } \mathbf{~ m g} / \mathbf{k g} \\
\text { TiO2 NPs }\end{array}$ & P value \\
\hline Corpus luteum & $11.83 \pm 1.32$ & $12.66 \pm 1.75$ & $8.66 \pm 1.21^{*}$ & $12.50 \pm 2.34$ & $\mathrm{P}<0.01$ \\
Growing follicle & $9.66 \pm 1.63$ & $11.33 \pm 2.25$ & $11.33 \pm 2.16$ & $7.50 \pm 1.87 \subseteq$ & $\mathrm{P}<0.05$ \\
Graafian follicle & $7.50 \pm 1.87$ & $7.83 \pm 1.47$ & $5.66 \pm 0.81 \Omega$ & $1.33 \pm 0.05 \Omega$ & $\mathrm{P}<0.001$ \\
\hline
\end{tabular}

*Significant reduction in the number of Corpus luteum $(\mathrm{P}<0.01)$

(C) Significant reduction in the number of Growing follicle $(\mathrm{P}<0.05)$

$\Omega$ Significant reduction in the number of Graaf follicle $(\mathrm{P}<0.001)$

\subsection{Histological studies}
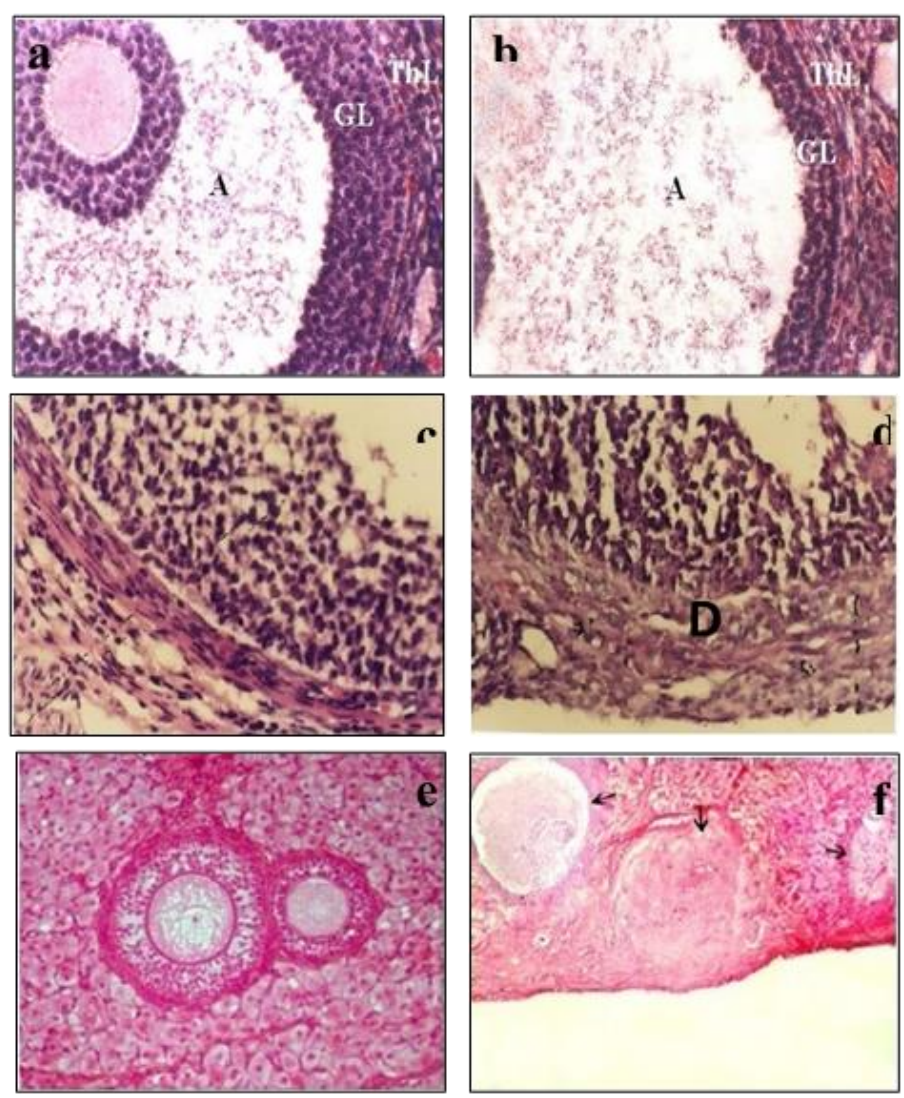

Figure 1 Sections of the ovary tissue in control and treated groups

(a) Graaf follicles in control group are normal, (b) treated group (150 mg/kg) shows loss of Graaf follicles and reducing the thickness of Granulosa and Thec layers, (c) growing follicles wall is regular in control group, (d) destruction of growing follicles wall in group $150 \mathrm{mg} / \mathrm{kg}$ (D), (e) follicles in control group are normal, (f) atretic follicles in group $150 \mathrm{mg} / \mathrm{kg}$ (arrows), (A, Follicular cavity; GL, Granulosa Layer; ThL, Thec Layer) (×400). 
Histological studies showed changes, including loss of Graafian follicles and reducing the thickness of Granulosa and Thec layers in $150 \mathrm{mg} / \mathrm{kg}$ group compared with control group. Moreover, the destruction of growing follicles wall was observed in this group. Also, atretic follicle was observed in 100 and $150 \mathrm{mg} / \mathrm{kg}$ treatments of TiO2 NPs (Fig 1).

\section{Discussion}

Titanium dioxide nanoparticles have very special physical and chemical properties for use in medical and biological fields [16-18] and it is necessary that their side effects have been investigated on the organisms especially in immature animals. In the present study, intraperitoneal injection of titanium dioxide nanoparticles in immature female rats showed significant differences in a dose-dependent manner (at concentrations of 100 and $150 \mathrm{mg} / \mathrm{kg}$ ) in the level of sex hormones and tissue structure of the ovary during puberty which included a significant increase in estrogen and progesterone levels, a decrease in the number of growing follicles, Corpus luteum and Graafian follicle. In general, because nanoparticles do not have a specific target tissue after entering the body [19, 20], precisely we can not justify the cause of these disorders. However, several studies similar to the present study have shown significant changes in levels of $\mathrm{LH}, \mathrm{FSH}$ and sex hormones after treatment with $\mathrm{TiO}_{2}$ nanoparticles [19-22], which have been reported to reduce fertility in some reports[19]. According to these researchers and other reports, the most common mechanism that the nanoparticles cause toxicity in the body, the production of free oxygen and hydrogen radicals consequently increased oxidative stress and ultimately by creating destructive effects on the membrane and cell structure in the various tissues that cause abnormalities in their function and structure [23-25]. Also, in several studies, the accumulation of titanium dioxide nanoparticles has been reported in subsequent injection in various organs such as gonads, which by binding to enzymes, different receptors, proteins, and even multiple genes, disrupting their function [20-22]. On the other hand, the probable accumulation of $\mathrm{TiO}_{2}$ in various components of the reproductive system, the gonads and the gonadpituitary axis, which is one of the most sensitive and complex physiological regulatory mechanisms, can cause severe fluctuations in the regulation of hormonal secretion [25,26]. Other findings from the present study showed a decrease in the number of ovarian follicles with abnormal walls, which was associated with significant fluctuations in sex hormones levels, because the growth and activity of the follicles are influenced by these hormones and they have several positive and negative feedback effects on each other [23]. Additionally, in the current study, immature rats were exposed to $\mathrm{TiO}_{2}$ nanoparticles, which the sensitivity of most organs and tissues, especially the gonads, is more than the period of puberty against various toxins including nanoparticles, because the gonadal development and the hormonal regulation pathways have not yet been completely developed [27]. Therefore, the time to use $\mathrm{TiO}_{2}$ nanoparticles in this study is also one of the important reasons for the occurrence of hormonal and tissue disorders.

\section{Conclusion}

Our results showed that 5 times repeated injections of $\mathrm{TiO}_{2}$ nanoparticles in pre-puberty at concentrations higher than $50 \mathrm{mg} / \mathrm{kg}$ caused significant changes in sex hormones levels, number of follicles and their histological structure. But it can't be safely concluded that these changes lead to reduced fertility. Therefore, further research is needed to examine the fertility of rats exposed to titanium dioxide nanoparticles during pre-puberty.

\section{Compliance with ethical standards}

\section{Acknowledgments}

The authors would like to thank from the department of Biology, Islamic Azad University, Falavarjan Branch for their cooperation and support.

\section{Disclosure of conflict of interest}

The authors declare no conflict of interest.

\section{Statement of ethical approval}

This research was approved in advance by the department of biology, Falavarjan branch, Islamic Azad University Ethics Committee. 


\section{References}

[1] Safavi K. (2014). Effect of Titanium Dioxide nanoparticles in plant tissue culture media for enhance resistance to bacterial activity. Bull Env Pharmacol Life Sci, 3 (5), 163-166.

[2] Mu Q, Jiang G and Yan B. (2014). Chemical basis of interactions between engineered nanoparticles and biological systems. Chem Rev, 114 (15), 7740-81.

[3] Wang F, Banerjee D, Liu Y, Chen X and Liu X. (2010). Upconversion nanoparticles in biological labeling, imaging, and therapy. Analyst, 135 (8), 1839-1854.

[4] Teng ZI, Lou Y and Wang Q. (2012). Nanoparticles Synthesized from Soy Protein: Preparation, Characterization, and Application for Nutraceutical Encapsulation. J. Agric. Food Chem, 60 (10), 2712-20.

[5] Abu-Dief EE, Khalil KM, Abdel-Aziz HO, Nor-Eldin EK and Ragab EE. (2015). Histological effects of Titanium Dioxide nanoparticles in adult male albino rat liver and possible prophylactic Eeffects of milk thistle seeds. Life Science Journal, 12 (2), 115-123.

[6] Shakibaie MR and Harati A. (2004). Metal accumulation in pseudomonas aeruginosa occur in the Form of nanoparticles on the cell surface. Iranian Journal of Biotechnology, 2 (5), 55-60.

[7] Albanese A, Tang PS and Chan WCW. (2012). The Effect of Nanoparticle Size, Shape, and Surface Chemistry on Biological Systems. Annu Rev Biomed Eng, 14, 1-16.

[8] Lee Y, Choi J, Kim P, Choi K, Kim S, Shon W and Park K. (2012). A transfer of Silver nanoparticles from pregnant rat to offspring. Toxicol Res, 28 (3), 139-141.

[9] Zhang C, Zhai S, Wu L, Bai Y, Jia J, Zhang Y, Zhang B and Yan B. (2015). Induction of Size-Dependent Breakdown of Blood-Milk Barrier in Lactating Mice by TiO2 Nanoparticles. PLoS ONE, 10 (4), 1-18.

[10] Nel A, Xia T, Madler L and Li N. (2006). Toxic potential of materials at the nanolevel. Science, 311 (5761), 622627.

[11] Peralta-Videa JR, Zhao L, Lopez-Moreno ML, Rosa G, Hong J and Gardea-Torresdey JL. (2011). Nanomaterials and the environment: A review for the biennium 2008-2010. J Hazard Mater, 186 (1), 1-15.

[12] Wang G. (2007). Hydrothermal synthesis and photocatalytic activity of nano crystalline $\mathrm{TiO}_{2}$ powder in ethanolwater mixed solutions. J Molec Catal A: Chaemical, 274 (1-2), 185-191.

[13] Li JJ, Muralikrishnan S, Ng CT, Yung LY and Bay BH. (2012). Nanoparticle-induced pulmonary toxicity. Exp Biol Med (Maywood), 235 (9), 1025-1033.

[14] Li Q, Mahendra S, Lyon DY, Brunet L, Liga MV, Li D and Alvarez PJJ. (2008). Antimicrobial nanomaterials for water disinfection and microbial control: Potential applications and implications. Water Research, 42 (18), 4591-4602.

[15] Dehghani N, Noori A and Modaresi M. (2014). Investigating the effect of Titanium Dioxide nanoparticles on the growth and sexual Maturation of male rats. International Journal of Basic Sciences \& Applied Research, 3 (11), 772-776.

[16] Mohammadi Fartkhooni F, Noori A and Mohammadi A. (2016). Effects of Titanium Dioxide nanoparticles toxicity on the kidney of male rats. International Journal of Life Sciences, 10 (1), 65-69.

[17] Hund-Rinke K and Simon M. (2006). Ecotoxic effect of photocatalytic active nanoparticles (TiO2) on algae and daphnids (8 pp). Environmental Science and Pollution Research, 13 (4), 225-232.

[18] Chen J, Dong X, Zhao J and Tang G. (2009). In vivo acute toxicity of titanium dioxide nanoparticles to mice after intraperitioneal injection. Journal of Applied Toxicology, 29 (4), 330-337.

[19] Wang J, Zhu X, Zhang X, Zhao Z, Liu H, George R and et al. (2011). Disruption of zebrafish (Danio rerio) reproduction upon chronic exposure to $\mathrm{TiO}_{2}$ nanoparticles. Chemosphere, 83 (4), 461-467.

[20] Pilger A, and Rudiger WH. (2006). 8-Hydroxy-2-deoxyguanosine as a marker of oxidative DNA damage related to occupational and environmental exposures. Int Arch Occup Environ Health, 80 (1), 1-15.

[21] Zhao X, Ze Y, Gao G, Sang X, Li B, Gui S and et al. (2013). Nanosized $\mathrm{TiO}_{2}$-Induced reproductive system dysfunction and its mechanism in female mice. PLOS ONE, 8 (4), 1-10.

[22] Livak KJ and Schmittgen TD. (2001). Analysis of relative gene expression data using real-time quantitative PCR and the 2(-Delta Delta C(T)) method. Methods, 25 (4), 402-408. 
[23] Amrit FRJ, Steenkiste EM, Ratnappan R, Chen SW, McClendon TB, Kostka D, Yanowitz J, Olsen CP and Ghazi A. (2016). DAF-16 and TCER-1 Facilitate Adaptation to Germline Loss by Restoring Lipid Homeostasis and Repressing Reproductive Physiology in C. elegans. PLOS GENETICS, 12 (10), 1-35.

[24] Runa S, Khanal D, Kemp ML and Payne CK. (2016). TiO2 Nanoparticles Alter the Expression of Peroxiredoxin Antioxidant Genes. J. Phys. Chem, 120 (37), 20736-742.

[25] Hou J, Wan XY, Wang FX and Liu Z. (2009). Effects of titanium dioxide nanoparticles on development and maturation of rat preantral follicle in vitro. Academ J Second Milit Med Univ, 30 (8), 869-873.

[26] Sampa G, Monomohon M, Ujjal B, Rajkumar M, Debnatha J and Ghosha D. (2001). Effect of human chorionic gonadotrophin coadministration on ovarian steroidogenic and folliculogenic activities in cyclophosphamide treated albino rats. Reprod Toxicol, 15 (2), 221-225.

[27] Lopez SG and Luderer U. (2004). Effects of cyclophosphamide and buthionine sulfoximine on ovarian glutathione and apoptosis. Free Radical Biol Med, 36 (11), 1366-77.

\section{How to cite this article}

Noori A, Baghbadorani AA and Golozar M. (2019). The effect of titanium dioxide nanoparticles injection in neonatal period on ovaries in mature rats. GSC Biological and Pharmaceutical Sciences, 6(1), 50-55. 